\title{
Synthesis, Characterization, Antimicrobial and Density Functional Theory Studies of Metal Complexes of 3-Benzoyl-7-methoxy Coumarin
}

\author{
S. RADHA, K. K. MOTHILAL ${ }^{1 *}$, A .THAMARAICHELVAN² AND R. SHANMUGAM ${ }^{3}$
}

Department of Chemistry, Saiva Bhanu Kshatriya College, Aruppukottai-626 101, ${ }^{1}$ Department of Chemistry, Saraswathi Narayanan College, Madurai-625 002, ${ }^{2}$ Chettinad Hospital and Research Institute, Chettinad Academy of Research and Education, Chennai-603 103, ${ }^{3}$ National Centre for Catalysis Research, Indian Institute of Technology Madras, Chennai-600 036, India

Radha et al.: Synthesis, antimicrobial, DFT studies, coumarin metal complexes

\begin{abstract}
A series of three metal complexes of the 3-benzoyl-7-methoxycoumarin ligand have been synthesized and characterized by elemental analyses, molar conductance, Fourier-transform infrared spectroscopy, thermogravimetric analysis, electron paramagnetic resonance, proton nuclear magnetic resonance spectroscopy and cyclic voltammetry techniques. The infra-red spectra of the ligand and its complexes showed that the ligand behaved as a bidentate and confirmed the presence of nitrate ions in the coordination sphere. Thermal stability of the complexes was studied using thermogravimetric and differential thermal analysis, which supported the presence of nitrate ions in these complexes. All complexes exhibited an octahedral geometry around the metal center. The redox property of the metal complexes was studied cyclic voltametrically, which showed that all the complexes exhibited quasi-reversible nature. Antimicrobial studies of these metal complexes and the ligand were conducted against Escherichia coli, Staphylococcus aureus, Pseudomonas aeruginosa and Aspergillus niger and Candida albicans. Metal complexes exerted greater antimicrobial activities compared to the ligand. The optimized structure of the zinc complex of coumarin derivative was obtained using DFT/RB3LYP method with 6-311G++G (d,p) basis set. Density functional theory calculations were performed for the determination of geometry structure and vibrational assignments for the zinc complex.
\end{abstract}

Key words: Metal complex, 3-benzoyl-7-methoxycoumarin, thermogravimetry, cyclic voltammetry, DFT, antimicrobial

Coumarin is a phytochemical compound ${ }^{[1]}$ existing in many plants such as Tonka bean, lavender, sweet clover grass, liquorice, strawberries, apricots, cherries, and cinnamon. Recently, coumarin derivatives are used to prepare new drugs with low toxicity and are being used as anticoagulants ${ }^{[2]}$, antibacterial agents ${ }^{[3]}$, antifungal agents $^{[4]}$, biological inhibitors ${ }^{[5]}$, chemotherapeutics ${ }^{[6,7]}$ and bioanalytical reagents ${ }^{[8]}$. These are useful antioxidants and show antitumor activity ${ }^{[9]}$ and cytotoxicity $^{[10-15]}$. Coumarin and its derivatives have been studied extensively for complexation with metal ions $^{[16-23]}$. Coumarin derivatives are known to have good complexing ability ${ }^{[24]}$. The formation of metal complexes with coumarin plays an important role in the growth of biological activity. Recently, it has been reported that 4-methyl-7-hydroxycoumarin complexes with several metals might be applicable as anticoagulants and spasmolytic agents ${ }^{[25,26]}$. Ferroquine, a metal complex, can produce reactive oxygen species (ROS), which kill the parasites resistant to chloroquine ${ }^{[27]}$. Luminescent metal complexes show selective binding affinity with specific DNA conformations ${ }^{[28]}$. Considerable effort has now been given to the functionalization of coumarin so that metal-coumarin complexes may be synthesized towards the development of artificial photosynthetic systems, chemical sensors, and molecular level devices ${ }^{[29]}$. In the present study, three metal complexes of 3-benzoyl-7-methoxycoumarin

This is an open access article distributed under the terms of the Creative Commons Attribution-NonCommercial-ShareAlike 3.0 License, which allows others to remix, tweak, and build upon the work non-commercially, as long as the author is credited and the new creations are licensed under the identical terms

Accepted 26 May 2018

Revised 16 October 2017

Received 21 February 2017

Indian J Pharm Sci 2018;80(4):619-627 
(L1) were synthesized and characterized using UV/ Vis, Fourier-transform infrared spectroscopy (FTIR), thermal studies, proton nuclear magnetic resonance spectroscopy ( $\left.{ }^{1} \mathrm{HNMR}\right)$, cyclic voltammetric analysis and antimicrobial activities with the aim of studying the nature of the chelating characteristics of the coumarin ligand with the metals.

\section{MATERIALS AND METHODS}

Coumarin derivatives, 3-benzoyl-7-methoxycoumarin and metal salts were purchased from Sigma Chemicals Co. (USA) and were used as received. Antibacterial activities of the drug/complexes were assessed using nutrient agar medium and antifungal activity using potato dextrose agar medium. The in vitro antibacterial and antifungal assays were performed employing agar well diffusion and disc diffusion method and the test bacteria and fungi used were, Staphylococcus aureus, Escherichia coli, Pseudomonas aeruginosa and Candida albicans and Aspergillus niger typed cultures, respectively and these were obtained from the American Type Culture Collection ${ }^{[30]}$. Inoculated organisms in nutrient broth media together with the prepared liquid Mueller-Hinton agar were poured into plates and allowed to solidify. Wells were bored into the solidified agar medium using a sterile $7 \mathrm{~mm}$ cork-borer. The wells were then filled with solution of prepared metal complexes and ligand (10 ppm) ensuring that the solution did not spill to the surface of the medium. The plates were allowed to stand for 1-2 $\mathrm{h}$ and for proper diffusion of the sample solution into the medium before incubating at $37^{\circ}$. Zones of inhibition formed were observed after $24 \mathrm{~h}$. Inhibition zone diameter was measured using a ruler with an accuracy of $0.5 \mathrm{~mm}$. A control experiment with dimethyl sulfoxide (DMSO) was also carried out.

\section{Physical measurements:}

The elemental analysis $(\mathrm{C}, \mathrm{H}$, and $\mathrm{N})$ of the sample was determined at SAIF, Cochin University, Cochin, Kerala. IR spectra were recorded on a Jasco 460 PLUS FTIR spectrophotometer using $\mathrm{KBr}$ pellets. A Shimadzu UV-3101PC spectrophotometer was used to record UV/ Vis spectra using cuvettes of $1 \mathrm{~cm}$ path length. ${ }^{1} \mathrm{HNMR}$ spectral measurements were made on a Brucker R300 MHz spectrometer in deuterated DMSO with tetramethylsilane as the internal standard. Conductivity measurements were carried out with DMSO solutions of complexes on an Elico conductivity bridge type CM 82 using a dip-type cell with a cell constant of 1.0. Cyclic voltammetry measurements were made on Princeton EG and G-PARC model potentiostat. Thermal analyses were performed on a Perkin Elmer Diamond instrument at a heating rate of $5 \% \mathrm{~min}$ under a dynamic air atmosphere $(150 \mathrm{ml} / \mathrm{min})$. All complexes were investigated in the temperature range $40-800^{\circ}$. All theoretical calculations were carried out using Gaussian 09 package and Gauss view molecular visualization programs. The basis sets $6-311++\mathrm{G}$ (d,p) was employed in the RB3LYP calculations. The geometry of the zinc complex (1c) was optimized in gas phase using density functional theory (RB3LYP method) and their vibrational frequencies were also computed at the same level of theory.

\section{Synthesis of metal complexes:}

A solution of 3-benzoyl-7-methoxycoumarin (L1, $\mathrm{C}_{17} \mathrm{H}_{12} \mathrm{O}_{4}, 0.560 \mathrm{~g}, 2 \mathrm{mmol}$ ) in $20 \mathrm{ml}$ of methanol was treated with a solution of nickel (II) nitrate $(0.290 \mathrm{~g}, 1 \mathrm{mmol})$ in methanol. The reaction mixture was stirred on a magnetic stirrer. Bluish green crystalline product formed after 6-7 $\mathrm{h}$ was collected by filtration. The solid was washed several times with methanol $(50 \mathrm{ml})$, then with diethyl ether $(30 \mathrm{ml})$ and finally dried in vacuum. The obtained complex (1a) was recrystallized from dry methanol. Molecular formula of $1 \mathrm{a}, \mathrm{NiC}_{34} \mathrm{H}_{24} \mathrm{O}_{14} \mathrm{~N}_{2}$ : molecular weight 743.23 , yield: $0.492 \mathrm{~g}$, colour: bluish-green powder. Copper (II) nitrate and zinc (II) nitrate were dissolved in methanol and added to a solution of L1 in methanol in 2:1 mole ratio of ligand to metal, respectively, with stirring. The reaction mixture was heated under reflux for 3-4 h, during this period the precipitation was completed and filtered. Then, the precipitates (1b and 1c) were washed with methanol and dried under vacuum for $3 \mathrm{~h}$. Molecular formula of $1 \mathrm{~b}$ was $\mathrm{Cu} \mathrm{C}_{34} \mathrm{H}_{24} \mathrm{O}_{14} \mathrm{~N}_{2}$, molecular weight 748.09 , yield, $0.589 \mathrm{~g}$, colour: brown powder; molecular formula of $1 \mathrm{c}$ was $\mathrm{ZnC}_{34} \mathrm{H}_{24} \mathrm{O}_{14} \mathrm{~N}_{2}$, molecular weight 749.92 , yield, $0.596 \mathrm{~g}$, colour: white crystals.

\section{RESULTS AND DISCUSSION}

The mononuclear complexes $1 \mathrm{a}$ and $1 \mathrm{~b}$ were in powdery form and complex $1 \mathrm{c}$ was in needle-shaped crystalline form. These complexes obtained from nitrates were soluble in organic solvents such as DMSO and dimethyl formamide. The complexes $1 \mathrm{a}, 1 \mathrm{~b}$ were colored, except 1c. All complexes were sparingly soluble in water and stable in air. The analytical data of these complexes showed that the solids were stable and can be stored for months without any significant change in their 
formulae. The structure of synthesized complexes has been shown in fig. 1. The molar conductivities of a $10^{-3} \mathrm{M}$ solution of these complexes were measured at room temperature. The lower conductance values obtained $0.12-0.24 \mathrm{ohm} / \mathrm{cm}^{2} / \mathrm{mol}$ of these complexes support their non-electrolytic nature. It also indicated that the nitrate anions bind to the metal ions as ligands and do not ionize.

The purity of the complexes were derived from $\mathrm{C}, \mathrm{H}$, $\mathrm{N}$ analysis and the results were found to be in good agreement with the calculated values given as follows: complex 1a found: C, $54.23 \%$; H, $2.97 \%$; O, $29.88 \%$; $\mathrm{N}, 3.39$; Ni, $7.62 \%$; $\mathrm{C}_{34} \mathrm{H}_{24} \mathrm{NiO}_{14} \mathrm{~N}_{2}$, calcd: C, $54.89 \%$; $\mathrm{H}, 3.23 \%$; O, $30.14 \%$; N, 3.77; Ni, $7.89 \%$; complex 1b found: $\mathrm{C}, 53.99 \% ; \mathrm{H}, 3.18 \% ; \mathrm{O}, 29.91 \%$, 3.47; $\mathrm{Cu}, 8.25 \% ; \mathrm{C}_{34} \mathrm{H}_{24} \mathrm{CuO}_{14} \mathrm{~N}_{2}$, calcd: $\mathrm{C}, 54.53 \%$; H, $3.21 \%$; O, $29.94 \%$; N, 3.74; Cu, $8.49 \%$; complex 1c found: C, $54.33 \%$; $3.09 \%$; O, $28.99 \%$; $\mathrm{N}, 3.64 ; \mathrm{Zn}, 8.28 \% \mathrm{C}_{34} \mathrm{H}_{24} \mathrm{ZnO}_{14} \mathrm{~N}_{2}$, calcd: C, $54.40 \%$; H, $3.23 \%$; O, $29.87 \%$; N, 3.73; Zn,8.72 \%.

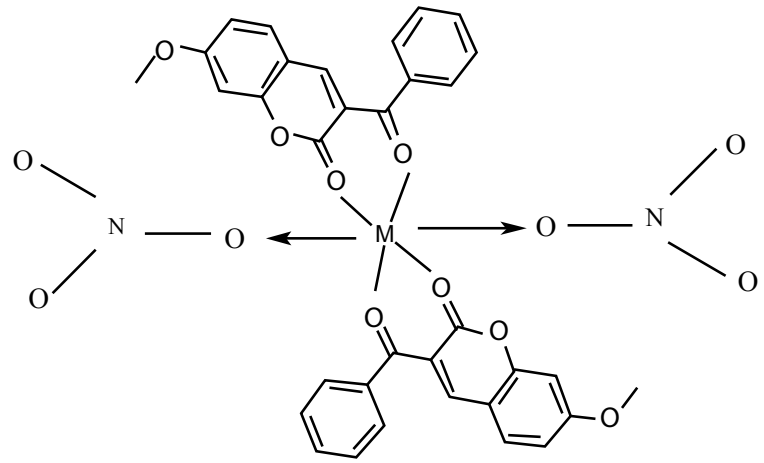

Fig. 1: Structure of the metal complexes $\mathrm{M}=\mathrm{Ni}, \mathrm{Cu}, \mathrm{Zn}$
The analysis of the FTIR spectra of the ligand and complexes were measured in the region 400$4500 \mathrm{~cm}^{-1}$. The IR spectrum of $1 \mathrm{a}$ was given in fig. 2, while the IR spectral data of the ligand and all complexes prepared were summarized in Table 1. New bands in the region $470-480 \mathrm{~cm}^{-1}$ in all the complexes were assigned to stretching frequencies of $(\mathrm{M}-\mathrm{O})$ bonds. In comparison with spectra of the ligand (L1), all metal complexes exhibited a downward shift of about 10$20 \mathrm{~cm}^{-1}$ of $\left(\mathrm{V}_{\mathrm{C}=\mathrm{O}}\right)$, indicating the participation of oxygen in coordination to the metal ion. Practically no effect on the frequencies of benzopyrone ring oxygen atom in L1 after complexation indicated non-involvement of these groups in coordination. The presence of two absorption bands at $1525-1480$ and the $1325-1283 \mathrm{~cm}^{-1}$ region is attributed to $v_{4}$ and $v_{1}$ modes, which indicated that the nitrate anions in the metal complexes were covalently bonded and present in the coordination sphere ${ }^{[31]}$. Thus, the IR spectral data provided strong evidence for complexation of the bidentate ligand L1.

The $n \rightarrow \pi^{*}$ characteristic band in the UV spectra of ligand assigned to the $\mathrm{C}=\mathrm{O}$ bond appear at $264 \mathrm{~nm}$ for carbonyl and is shifted toward higher wavelengths with 6,7 and $4 \mathrm{~nm}$ for complex $1 \mathrm{a}, 1 \mathrm{~b}$ and $1 \mathrm{c}$, respectively confirming the presence of the ligand in the complex and the covalent nature of the metal-ligand bond. In the visible domain, the $d-d$ transition appears between at $645 \mathrm{~nm}$ in the copper complex. In the visible domain, nickel complex 1a showed a band at $508 \mathrm{~nm}$ attributed to the $d-d$ transition ${ }^{3} \mathrm{~A}_{2 \mathrm{~g}}(\mathrm{~F}) \rightarrow{ }^{3} \mathrm{~T}_{1 \mathrm{~g}}(\mathrm{~F}),{ }^{3} \mathrm{~A}_{2 \mathrm{~g}}(\mathrm{~F}) \rightarrow{ }^{3} \mathrm{~T}_{2 \mathrm{~g}}(\mathrm{~F})$, ${ }^{3} \mathrm{~A}_{2 \mathrm{~g}}(\mathrm{~F}) \rightarrow{ }^{3} \mathrm{~T}_{1 \mathrm{~g}}(\mathrm{P})$. Complex $1 \mathrm{~b}$ has been assigned to

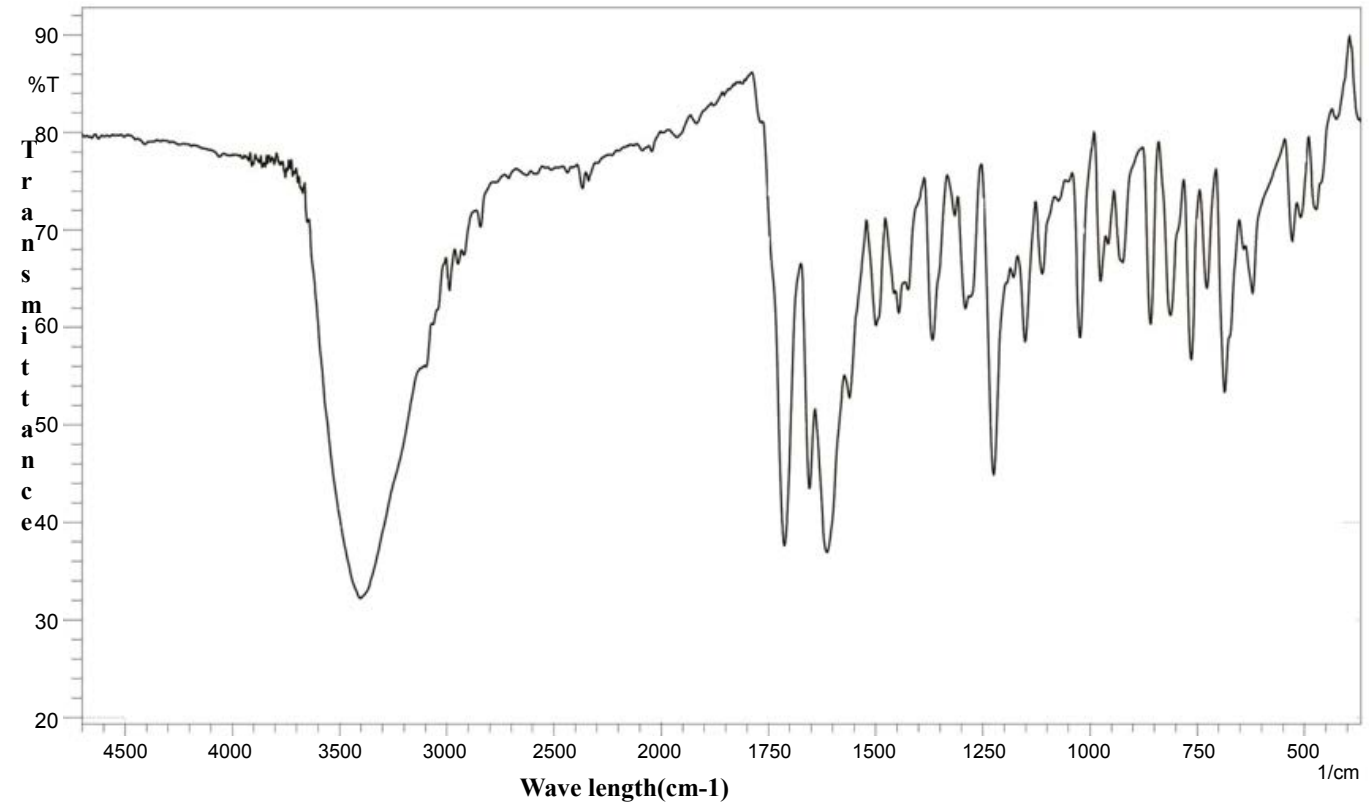

Fig. 2: IR spectrum of the Ni complex 1a 
$\mathrm{E}_{2 \mathrm{~g}} \rightarrow{ }^{2} \mathrm{~T}_{2 \mathrm{~g}}$, which was in conformity with octahedral geometry. Zn (II) complex 1c attributed to the ligand to metal charge transition, which was compatible with this complex having an octahedral symmetry of zinc ion.

${ }^{1}$ HNMR spectroscopy has proved to be a useful technique in the study of metal complexes. ${ }^{1} \mathrm{HNMR}$ spectra of the compounds were recorded at $250 \mathrm{MHz}$ in $\mathrm{CDCl}_{3}\left(\mathrm{MSO}-\mathrm{d}^{6}\right) .{ }^{1} \mathrm{HNMR}$ spectra of complexes $1 \mathrm{a}$ and $1 \mathrm{~b}$ were given in fig. $3 \mathrm{~A}$ and $\mathrm{B}$. Comparison of the ${ }^{1} \mathrm{H}-\mathrm{NMR}$ spectra of complexes with $\mathrm{L} 1$ revealed that the resonances were considerably broadened and also shifted on complexation. Well resolved multiplets at 7.60-7.72 $\delta$ corresponded to five aromatic protons in L1. In all complexes, multiplets corresponded to aromatic protons were shifted to the lower field due to complexation. The ${ }^{1} \mathrm{HNMR}$ spectra showed multiplet signals at 6.9-8.1 due to one olefinic proton (proton of lactone ring) and eight aromatic protons. In the ${ }^{1} \mathrm{HNMR}$ spectra of complexes, $1 \mathrm{a}$ and $1 \mathrm{~b}$, the signals at 3.92-3.95 due to methyl protons of the $\mathrm{OCH}_{3}$ group $\left(3 \mathrm{H}, \mathrm{OCH}_{3}\right)$.

TABLE 1: IMPORTANT INFRARED FREQUENCIES $\left(\mathrm{cm}^{-1}\right)$ OF FREE LIGAND L1 AND ITS METAL COMPLEXES (THEORETICAL AND EXPERIMENTAL)

\begin{tabular}{|c|c|c|c|c|c|c|c|c|c|c|}
\hline Ligand/Complex & $\mathbf{V}_{(\mathrm{C}=0)}$ & $v_{(c-c)}$ & $v_{(c-0)}$ & $v_{(\mathrm{C}-\mathrm{O}-\mathrm{C})}$ & $\mathbf{v}_{(M-0)}$ & $\mathbf{v}_{\text {(NO3) }}$ & $\mathbf{v}_{(\mathrm{C}=\mathrm{C})}$ & $\mathbf{V}_{(\mathrm{C}-\mathrm{H})}$ & $\mathbf{V}_{(\mathrm{C}-\mathrm{H}) \mathrm{ph}}$ & $\mathbf{v}_{(\mathrm{C}-\mathrm{H}) \mathrm{py}}$ \\
\hline $\mathrm{C}_{17} \mathrm{H}_{12} \mathrm{O}_{4} \mathrm{~L} 1$ & 1713 & 1226 & 1185 & 1022 & $-\cdots+-$ & $\cdots$ & 1652 & 3047 & 1364 & 1075 \\
\hline $\mathrm{C}_{34} \mathrm{H}_{24} \mathrm{NiO}_{14} \mathrm{~N}_{2}, 1 \mathrm{a}$ & 1725 & 1230 & 1205 & 1025 & 471 & 1367 & 1630 & $\cdots$ & $\cdots$ & $\cdots$ \\
\hline $\mathrm{C}_{34} \mathrm{H}_{24} \mathrm{CuO}_{14} \mathrm{~N}_{2}, 1 \mathrm{~b}$ & 1720 & 1224 & 1200 & 1024 & 476 & 1381 & 1625 & $\cdots$ & $\cdots$ & -- \\
\hline $\mathrm{C}_{34} \mathrm{H}_{24} \mathrm{ZnO}_{14} \mathrm{~N}_{2}, 1 \mathrm{C}$ & 1730 & 1234 & 1215 & 1013 & 474 & 1390 & 1634 & 3090 & 1320 & 1097 \\
\hline $\begin{array}{l}\mathrm{C}_{34} \mathrm{H}_{24} \mathrm{ZnO}_{14} \mathrm{~N}_{2}, 1 \mathrm{C} \\
\text { (Theoretical value) }\end{array}$ & 1742 & 1262 & 1210 & 1054 & 460 & 1365 & 1649 & 3041 & 1352 & 1092 \\
\hline
\end{tabular}
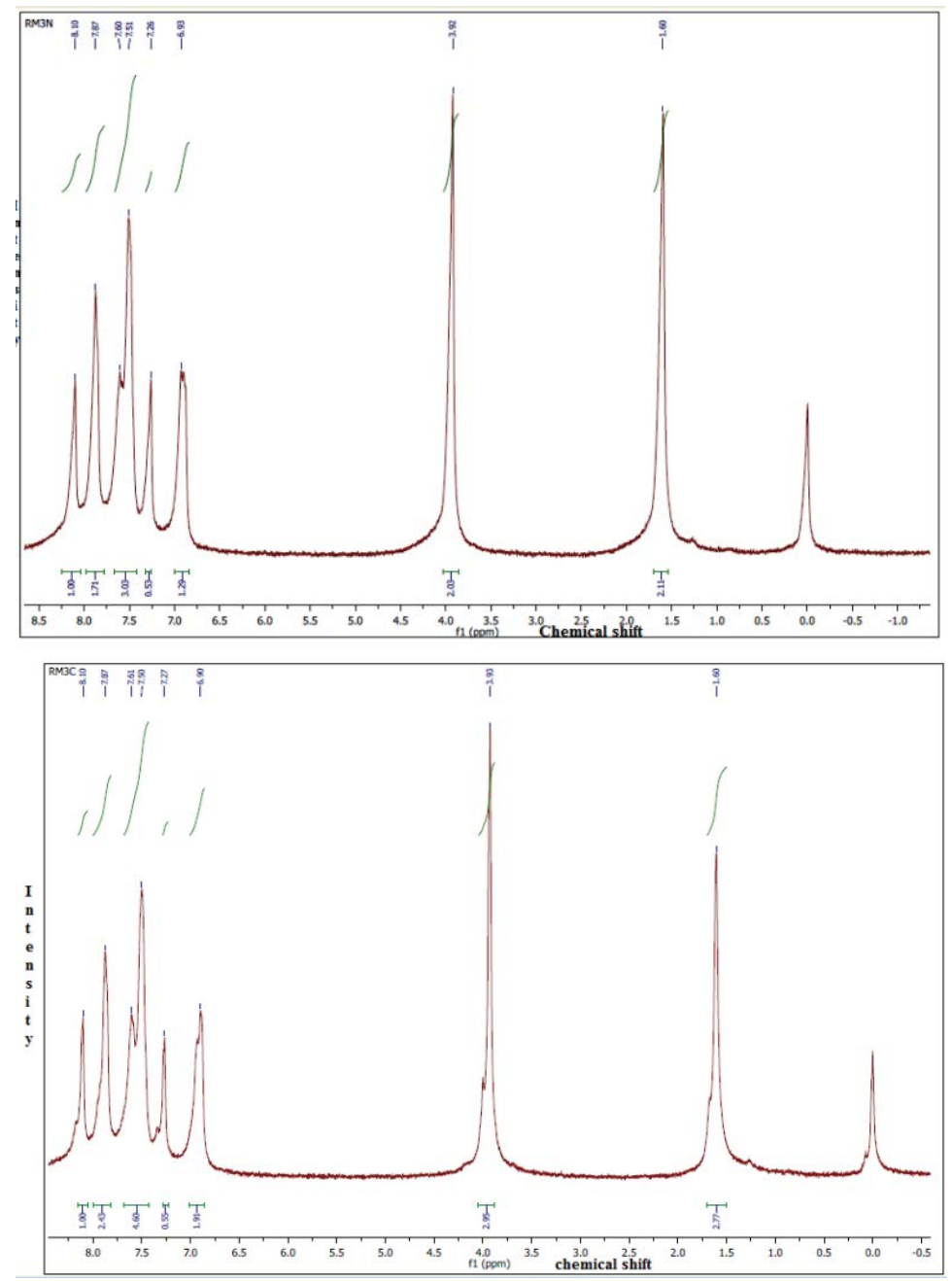

Fig. 3: ${ }^{1} \mathrm{H}-\mathrm{NMR}$ spectrum of the Ni complex of ligand L1, 1a; Cu complex of ligand L1, 1b 


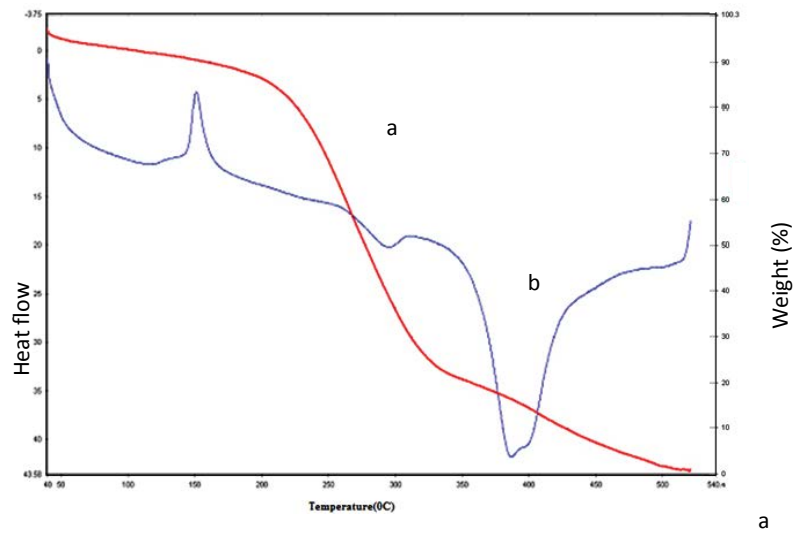

Fig. 4: Superimposed thermogravimetric, differential scanning calorimetric curves for $\mathrm{Ni}$ complex, 1a

a: Thermogravimetric curve and b: differential scanning calorimetric curves for $\mathrm{Ni}$ complex, 1 a under $\mathrm{N}_{2}$ atmosphere; heating rate: $10 \% \mathrm{~min}$

The thermal behaviour of $\mathrm{Ni}$ complex 1a has been illustrated in fig. 4. In the first step, thermal decomposition corresponding to $150^{\circ}$ is due to loss of L1 molecule. Further, the thermal decomposition occurs in the second step as indicated around at $295^{\circ}$ of $15.66-$ $16.32 \%$ (calcd: $16.68 \%$ ) mass loss of two coordinated nitrate anion in all complexes by an exothermic effect. The metal complexes decompose gradually with the formation of metal oxide at above $500^{\circ}$.

The cyclic voltammetric behaviour of complexes was recorded in the range from +1.2 to $-2.0 \mathrm{~V}$ at a scan rate of $0.1 \mathrm{Vs}^{-1}$. The typical cyclic voltammogram of complexes have, on the direct (cathodic) scan, two very well-defined cathodic waves with a first cathodic peak situated at less negative cathodic potentials and with a second cathodic peak situated at more negative cathodic potentials. A cyclic voltammogram of complex 1(a) in fig. 5 showed oxidation potential at $+0.682 \mathrm{~V}$ corresponding reduction at the potential at $-1.194 \mathrm{~V}$. The peak separation of this couple $(\Delta \mathrm{Ep})$ is $0.6478 \mathrm{~V}$ at $0.1 \mathrm{~V}$ and increases with scan rate. The difference between forward and backward peak potentials provides a rough evaluation of the degree of reversibility of the one-electron transfer reaction. The ratio of cathodic to anodic peak height was less than one, but the peak current increases with an increase of the square root of the scan rates, establishing the electrode process as diffusion controlled one ${ }^{[32]}$. The separation in peak potentials increasing at higher scan rates is consistent with quasi-reversibility of the $\mathrm{Cu}(\mathrm{II}) /$ $\mathrm{Cu}(\mathrm{I})$ couple.

Both ligand (L1) and metal complexes have been screened for their antimicrobial activity against pathogenic bacteria Gram-negative: E. coli,
$P$. aeruginosa, Gram-positive: $S$. aures and pathogenic fungi $C$. albicans, $A$. niger (Table 2). Metal complexes have higher biological activities against compared to the free ligand (L1). This can be explained on the basis of Tweedy's chelation theory ${ }^{[33]}$. Several factors such as delocalization of $\pi$ electrons over the chelate ring, increasing lipophilic character of metal complexes and presence of electron releasing group in the complexes enhance the inhibition activity of the metal complexes over the ligand. Complex 1(c) showed a good antifungal and antibacterial activity. The antimicrobial activity is found to be in the order: $1(\mathrm{c})>1(\mathrm{~b})>1(\mathrm{a})>\mathrm{L} 1$. The zinc complex (1(c)) is found to generate more ROS and exhibit greater antimicrobial activity and it follows the natural order (Irving-Williams order) of stability of the complexes $^{[34]}$.

The optimized structure parameters of the complex 1c as calculated by DFT/RB3LYP levels with the

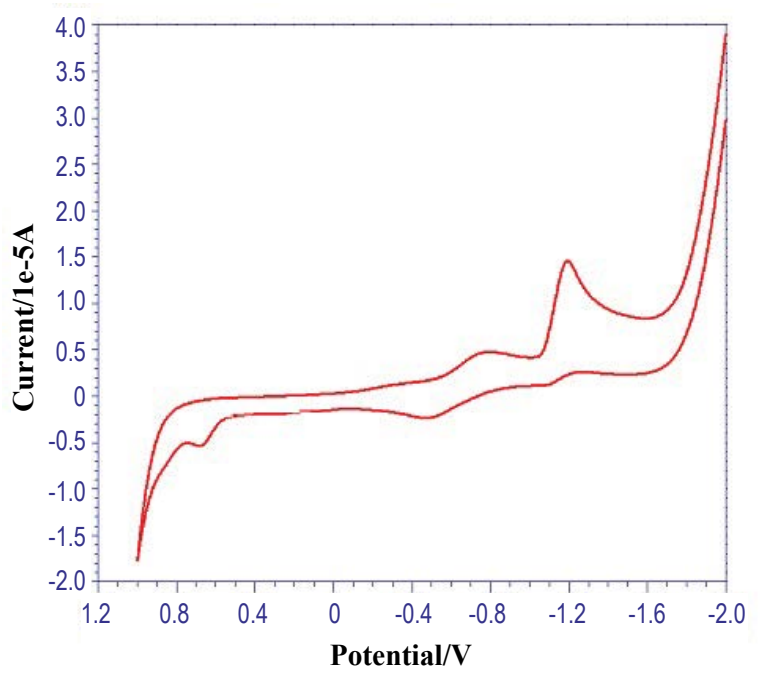

Fig. 5: Cyclic voltammogram of the Ni complex 1a DMSO with $0.5 \mathrm{M} \mathrm{NBu}_{4} \mathrm{ClO}_{4}$ as supporting electrolyte and scan rate at $50 \mathrm{mVs}^{-1}$

TABLE 2: ANTIMICROBIAL ACTIVITIES OF LIGAND (L1) AND ITS METAL COMPLEXES 1a, 1b, 1c

\begin{tabular}{cccc}
\hline Ligand & \multicolumn{3}{c}{ Zone of inhibition $(\mathrm{mm})$} \\
\cline { 2 - 4 } complexes & S. aures & P. aeruginosa & E. coli \\
\hline L1 & 8 & 9 & 5 \\
1a & 10.5 & 10 & 6.5 \\
1b & 12 & 11.5 & 9 \\
1c & 14 & 13 & 11 \\
Ligand & C. albicans & A. niger & \\
complex & 7 & 5 & \\
L1 & 7 & 7.5 & \\
1a & 9 & 10 & \\
1b & 12 & 12 & \\
1c & 15 & \multicolumn{2}{c}{} \\
\hline
\end{tabular}

Note: Results are expressed as values appearing more than three times in the five/six parallel determinations 
6-311G $++\mathrm{G}(\mathrm{d}, \mathrm{p})$ basis set were listed in Table 3 . The DFT method is involved in using the restricted closedshell model (Becke 3-parameter exchange functional together with the restricted Lee-Yang-Parr correlation functional; RB3LYP). The B3LYP functional has been successfully used in some previous reports for geometry optimization of transition metal complexes ${ }^{[35,36]}$. The selected bond lengths, bond angles and dihedral angles of the metal complex 1c were listed in Table 3. From the values of geometrical parameters around the central metal ions, the generic basis set $6-311 \mathrm{G}++\mathrm{G}(\mathrm{d}, \mathrm{p})$ was found to be more appropriate for calculations on the complex $1 \mathrm{c}$. The complex 1c, optimized with the generic basis set, has distorted octahedral geometry around the central metal ions, shown in fig. 6. The octahedral structure of $1 \mathrm{c}$ is confirmed by the dihedral angles and bond angles, which showed that the two oxygen atoms in the nitrate ligand (O68 and O69) were roughly in the same plane that contained the central $\mathrm{Zn}$ (II) ion. The IR frequencies of the zinc complex 1c were obtained theoretically by DFT/B3LYP calculations employing the standard $6-311++\mathrm{G}(\mathrm{d}, \mathrm{p})$ basis set for optimized geometries and compared within the region of $400-4000 \mathrm{~cm}^{-1}$. Using Gauss View 5.0 molecular visualization program, the vibrational frequency assignments and other parameters are made. The calculated and experimental IR gas phase frequencies and their probable assignments for ligand and its zinc complexes are listed in Table 1. All calculations are given for optimized structure in the gas phase. The assignment of the experimental frequencies is based on the observed band frequencies in the infrared spectra of this species confirmed by establishing one to one correlation between observed and theoretically calculated frequencies in fig. 7. In the metal complex, $\mathrm{C}=\mathrm{O}$ group of coumarin ligand actively participates in

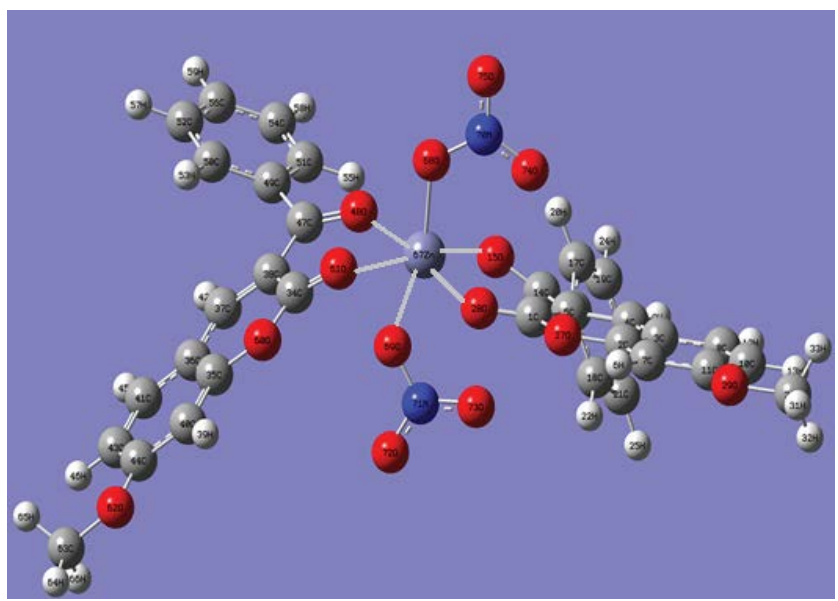

Fig. 6: Optimized geometry of the $\mathrm{Zn}$ complex 1c at B3LYP/ 6- $311++G^{* *}$ basis set
TABLE 3: BOND LENGTH, BOND ANGLE AND DIHEDRAL ANGLE OF Zn COMPLEX 1c

\begin{tabular}{|c|c|}
\hline Bond & Bond length $(\AA)$ \\
\hline $\mathrm{C} 1-\mathrm{C5}$ & 1.4529 \\
\hline $\mathrm{C} 1-027$ & 1.3619 \\
\hline $\mathrm{C} 1-028$ & 1.2419 \\
\hline O28-Zn67 & 2.0551 \\
\hline Zn67-015 & 2.0523 \\
\hline Zn67-070 & 2.2591 \\
\hline O70-H71 & 0.9786 \\
\hline O70-H73 & 0.9786 \\
\hline Zn67-068 & 2.2345 \\
\hline $\mathrm{O} 68-\mathrm{H} 29$ & 0.9719 \\
\hline O68-H72 & 0.9807 \\
\hline Zn67-048 & 2.0672 \\
\hline O61-Zn67 & 2.0794 \\
\hline C47-C49 & 1.4808 \\
\hline C49-C51 & 1.4122 \\
\hline C41-C43 & 1.3889 \\
\hline Bond angle & $\operatorname{Deg}\left({ }^{\circ}\right)$ \\
\hline 028-Zn67-015 & 85.68 \\
\hline $028-Z n 67-068$ & 92.13 \\
\hline O68-Zn67-061 & 91.48 \\
\hline O61-Zn67-048 & 83.72 \\
\hline 048-Zn67-070 & 87.85 \\
\hline 070-Zn67-015 & 76.67 \\
\hline $\mathrm{O} 27-\mathrm{C} 2-\mathrm{C} 3$ & 119.56 \\
\hline $\mathrm{O} 27-\mathrm{C} 2-\mathrm{C} 7$ & 117.22 \\
\hline $\mathrm{C} 2-\mathrm{C} 3-\mathrm{C} 4$ & 118.20 \\
\hline $\mathrm{C} 3-\mathrm{C} 4-\mathrm{C} 5$ & 122.15 \\
\hline $\mathrm{C} 7-\mathrm{C} 2-\mathrm{C} 3$ & 123.22 \\
\hline C7-C11-C10 & 119.85 \\
\hline $\mathrm{C} 11-\mathrm{C} 10-\mathrm{C} 8$ & 120.08 \\
\hline Zn67-048-C47 & 83.81 \\
\hline $\mathrm{H} 72-068-\mathrm{H} 69$ & 105.30 \\
\hline 070-Zn67-068 & 163.36 \\
\hline Dihedral angle & $\operatorname{Deg}\left({ }^{0}\right)$ \\
\hline Zn67-028-C1-C5 & -18.93 \\
\hline Zn67-015-C14-C5 & -14.30 \\
\hline O28-C1-C5-C14 & -3.16 \\
\hline O69-Zn67-028-C1 & -99.84 \\
\hline O70-Zn67-015-C14 & -107.80 \\
\hline O61-Zn67-048-C47 & -24.12 \\
\hline C34-061-Zn67-048 & 38.16 \\
\hline O34-C47-C38-C34 & 23.56 \\
\hline Zn67-061-C34-060 & 151.37 \\
\hline O70-Zn67-061-C34 & -49.38 \\
\hline O70-Zn67-048-C47 & 69.16 \\
\hline O70-Zn67-028-C1 & 94.18 \\
\hline 070-Zn67-015-C14 & -107.80 \\
\hline O68-Zn67-061-C34 & 114.59 \\
\hline O68-Zn67-028-C1 & -79.90 \\
\hline O68-Zn67-015-C14 & 88.59 \\
\hline
\end{tabular}

chelation and it shows a change in frequency value, corresponding to the partial loss of double bond 
character. The $\mathrm{C}=\mathrm{O}$ stretching vibrations are generally observed in the region around 1730-1745 $\mathrm{cm}^{-1}$. In the present study, the stretching vibrations of $\mathrm{M}-\mathrm{O}$ occurred at $460-475 \mathrm{~cm}^{-1}$ in the FTIR spectrum. Generally, the $\mathrm{C}=\mathrm{C}$ stretching vibrations in aromatic compounds form the band in the region of $1430-1650 \mathrm{~cm}^{-1[37]}$. For zinc

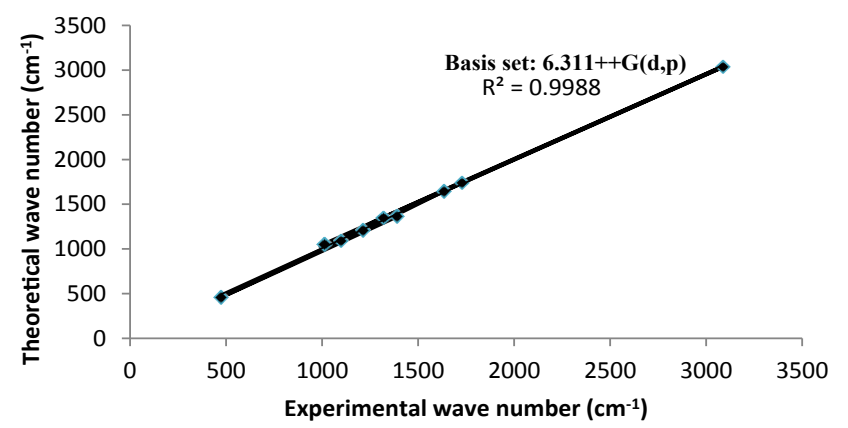

Fig. 7: Relationship between theoretical and experimental wave numbers

A linearity between the experimental and calculated wave numbers for the complex 1c (i.e. for the whole spectral range considered), can be estimated by plotting the calculated versus experimental wave numbers complex 1c, the prominent peaks at $1649 \mathrm{~cm}^{-1}$ were due to strong $\mathrm{C}=\mathrm{C}$ stretching vibrations and a strong peak at $1054 \mathrm{~cm}^{-1}$ is assigned to C-O-C stretching modes. The nitrate stretching vibration occurs around $1368 \mathrm{~cm}^{-1}$ is close to the theoretical value $\left(1365 \mathrm{~cm}^{-1}\right)$. Comparison between the calculated vibrational frequencies and the experimental values indicates that DFT/B3LYP can predict the FTIR spectrum of the zinc complex 1c well shown in fig. 8 .

The present work focuses on the synthesis, characterization, DFT calculations and biological studies of transition metal complexes of coumarin derivative as a ligand. The structural information obtained from these complexes is in agreement with the data reported in this paper based on the elemental, thermal analyses and NMR studies. The IR and thermal studies confirmed the presence of nitrate ions in the coordination sphere. Suggested structure of complexes may be $\left[\mathrm{M}(\mathrm{L} 1)_{2}\left(\mathrm{NO}_{3}\right)_{2}\right]$. All the complexes have octahedral coordination in which the metal ions are

A.
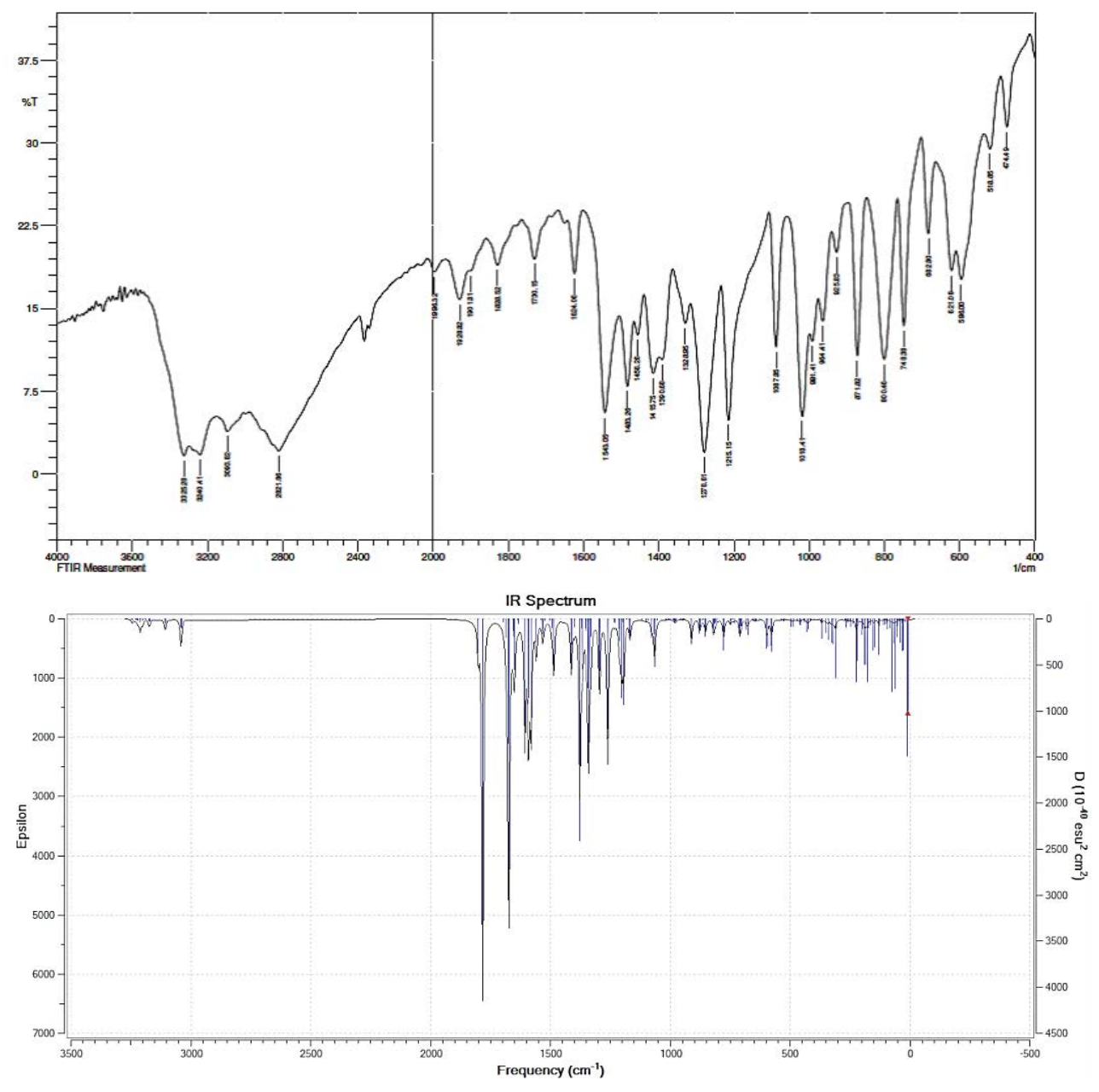

Fig. 8: Experimental (a) and theoretical (b) FTIR spectra of the complex 1c Calculated at B3LYP/ 6-311++G (3d.p) 
coordinated to ligand molecule as bidentate and nitrate ions as monodentate. Cyclic voltammetry studies of the metal complexes revealed the reversible and quasi-reversible one electron transfer redox processes respectively. The antimicrobial study reveals that metal complexes have more biological activity than the free ligand L1. Complex 1c showed the best antimicrobial activity against all microorganisms. DFT calculations have performed on the zinc complex 1c by a RB3LYP method with $6.311++\mathrm{G}(\mathrm{d}, \mathrm{p})$ basis set. The geometry of the zinc complex $1 \mathrm{c}$ has optimized and calculated IR frequencies are compared with the experimental values and good agreements are found.

\section{Acknowledgements:}

One of the authors S. Radha is grateful to the Management of Saiva Bhanu Kshatriya College, Aruppukottai, Tamilnadu, India for providing facilities and granting permission to carry out this research work.

\section{Financial support and sponsorship:}

Nil.

\section{Conflicts of interest:}

There are no conflicts of interest.

\section{REFERENCES}

1. Mendez MJ, Brown SA. The Natural Coumarins: Occurrence, Chemistry and Biochemistry. Chichester: Wiley and Sons; 1982.

2. Suttie JW. Warfarin and vitamin K. Clin Cardiol 1990;13(4):16-8.

3. Bedair AH, El-Hady NA, Abd El-Latif MS, Fakery AH, El-Agrody AM. 4-hydroxycoumarin in heterocyclic synthesis: Part III. Synthesis of some new pyrano[2,3- $d]$ pyrimidine, 2-substituted $[1,2,4]$ triazolo[1,5-c] pyrimidine and pyrimido[ $[1,6-b][1,2,4]$ triazinederivatives. Farmaco 2000;55:708-14.

4. Patonay T, Litkei G, Bognar R, Eredi J, Miszti C. Synthesis, antibacterial and antifungal activity of 4-hydroxycoumarin derivatives, analogues of novobiocin. Pharmazie 1984;39(2):86-91.

5. Gnerre C, Catto M, Leonetti F, Weber P, Carrupt PA, Altomare $\mathrm{C}$, et al. Inhibition of monoamine oxidases by functionalized coumarin derivatives: biological activities, QSARs and 3D-QSARs. J Med Chem 200043(25):4747-58.

6. Egan D, James P, Cooke D, O'Kennedy R. Studies on the cytostatic and cytotoxic effects and mode of action of 8-nitro7-hydroxycoumarin. Cancer Lett 1997;118(2):201-11.

7. Budzisz E, Keppler BK, Giester G, Wozniczka M, Kufelnicki A, Nawrot B. Synthesis, crystal structure, theoretical calculation and cytotoxic effect of new $\mathrm{Pt}(\mathrm{II}), \operatorname{Pd}(\mathrm{II})$ and $\mathrm{Cu}(\mathrm{II})$ complexes with pyridine-pyrazoles derivatives. Eur J Inorg Chem 2004;2004(2):4412-19.

8. Jime'nez M, Mateo JJ, Mateo R. Determination of type A trichothecenes by high-performance liquid chromatography with coumarin-3-carbonyl chloride derivatisation and fluorescence detection. J Chromatogr A 2000;870(12):473-81.

9. Koshy J, Kumar Das VG, Balabaskaran S, Ng SW, Wahab N. High In vitro Antitumour Activity of Triphenyltin Coumarin 3-Carboxylate and its Coordination Complexes With Monodentate Oxygen Donor Ligands Against the Epstein Barr Virus (EBV)-DNA Positive Raji and the P-388 Murine Leukaemia Cell Lines, and Evidence for the Suppression by Organotin of the Early Antigen Complex in the EBV Lytic Cycle. Met Based Drugs 2000;7(5):245-51.

10. Finn GJ, Kenealy E, Creaven BS, Egan DA. In vitro cytotoxic potential and mechanism of action of selected coumarins, using human renal cell lines. Cancer Lett 2002;183(1):61-78.

11. Thati B, Noble A, Creaven BS, Walsh M, McCann M, Kavanagh $\mathrm{K}$, et al. In vitro antitumour and cyto-selective effects of coumarin-3-carboxylic acid and three of its hydroxylated derivatives, along with their silver-based complexes, using human epithelial carcinoma cell lines. Cancer Lett 2007;248(2):321-31.

12. Yang H, Jiang B, Reynertson KA, Basile MJ, Kennelly EJ. Comparative analyses of bioactive mammea coumarins from seven parts of Mammea americana by HPLC-PDA with LCMS. J Agric Food Chem 2006;54(12):4114-20.

13. del Rayo Camacho M, Phillipson JD, Croft SL, Yardley V, Solis PN. In vitro antiprotozoal and cytotoxic activities of some flavonoids. Planta Med 2004;70(1):70-2.

14. Finn GJ, Creaven B, Egan DA. Study of the in vitro cytotoxic potential of natural and synthetic coumarin derivatives using human normal and neoplastic skin cell lines. Melanoma Res 2001;11(5):461-7.

15. Datta P, Mukhopadhyay AP, Manna P, Tiekink ER, Sil PC, Sinha C. Structure, photo physics, electrochemistry, DFT calculation and in-vitro antioxidant activity of coumarin Schiff base complexes of Group 6 metal carbonyls. J Inorg Biochem 2011;105(4):577-88.

16. Kulkarni AD, Bagihalli GB, Patil SA, Badami PS. Synthesis, characterization, electrochemical and in vitro antimicrobial studies of $\mathrm{Co}$ (II), $\mathrm{Ni}$ (II) and $\mathrm{Cu}(\mathrm{II})$ complexes with Schiff bases of formyl coumarin derivatives. J Coord Chem 2009;62:3060-72.

17. Alghool S. Metal complexes of azocoumarin derivative: synthesis, spectroscopic, thermal, and antimicrobial studies. J Coord Chem 2010;63:3322-33.

18. Thornes RD, Daly L, Lynch G, Breslin B, Browne H, Browne HY, et al. Treatment with coumarin to prevent or delay recurrence of malignant melanoma. J Cancer Res Clin Oncol 1994;120:S32-4.

19. Marshall ME, Mohler JL, Edmonds K, Williams B, Butler K, Ryles $\mathrm{M}$, et al. An updated review of the clinical development of coumarin (1,2-benzopyrone) and 7-hydroxycoumarin. J Cancer Res Clin Oncol 1994;120: S39-2.

20. Mohler JL, Williams BT, Thompson IM, Marshall ME. Coumarin (1,2-benzopyrone) for the treatment of prostatic carcinoma. J Cancer Res Clin Oncol 1994;120:S35-8.

21. Dömötör O, Tuccinardi T, Karcz D, Walsh M, Creaven BS, Enyedy EA. Interaction of anticancer reduced Schiff base coumarin derivatives with human serum albumin investigated by fluorescence quenching and molecular modeling. Bioorg Chem 2014;52:16-23.

22. Lake BG. Coumarin metabolism, toxicity and carcinogenicity: Relevance for human risk assessment. Food Chem Toxicol 1999;37(4):423-53. 
23. Marshall ME, Butler K, Fried A. Phase I evaluation of coumarin (1,2-benzopyrone) and cimetidine in patients with advanced malignancies. Mol Biother 1991;3(3):170-78.

24. Marshall ME, Kervin K, Benefield C, Umerani A, AlbainyJenei S, Zhao Q, et al. Growth-inhibitory effects of coumarin (1, 2-benzopyrone) and 7-hydroxycoumarin on human malignant cell lines in vitro. J Cancer Res Clin Oncol 1994;120:S3-10.

25. Myers RB, Parker M, Grizzle WE. The effects of coumarin and suramin on the growth of malignant renal and prostatic cell lines. J Cancer Res Clin Oncol 1994;120:S11-3.

26. Kawaii S, Tomono Y, Ogawa K, Sugiura M, Yano M, Yoshizawa Y. The antiproliferative effect of coumarins on several cancer cell lines. Anticancer Res 2001;21:917-23.

27. Gasser G. Metal complexes and medicine: A successful combination. Chimia 2015;69(7):442-46.

28. Lin S, Gao W, Tian Z, Yang C, Lu L, Mergny JL, et al. Luminescent switch-on detection of protein tyrosine kinase-7 using a G-quadruplex- selective probe. Chem Sci 2015;7:4284-90.

29. Sathisha MP, Shetty UN, Revankar VK, Pai KSR. Synthesis and antitumor studies on novel $\mathrm{Co}(\mathrm{II}), \mathrm{Ni}(\mathrm{II})$ and $\mathrm{Cu}(\mathrm{II})$ metal complexes of bis(3-acetylcoumarin)thiocarbohydrazone. Eur J Med Chem 2008;43(11):2338-46.
30. Wajid A, Mohod RB. Synthesis of amino acid based Schiff base and its complexes as microbial growth inhibitors. Rasayan J Chem 2013;6(4):284-87.

31. Addison CC, Logan N. Anhydrous metal nitrates. Adv Inorg Chem Radiochem 1964;6:71-142.

32. Bard AJ, Faulkner LR. Electrochemical methods: Fundamentals and Applications. 2nd ed. New York: John Wiley \& Sons, Inc.; 2001.

33. Tweedy BG, Turner N. Possible mechanism for reduction of sulphur by Monilinia fructicola. Phytopathology 1964;55: 910-14.

34. Mothilal KK, Karunakaran C, Rajendran A, Murugesan R. Synthesis, X-ray crystal structure, antimicrobial activity and photodyanamic effect of some Thiobendazole complexes. J Inorg Biochem 2004;98(2):322-32.

35. Chen L, Liu T, Ma C. Metal complexation and biodegradation of EDTA and S, S-EDDS: a density functional theory study. J Phys Chem A 2010;114(1):443-54.

36. Niu Y, Feng S, Ding Y, Qu R, Wang D, Han J. Theoretical investigation on sulfur-containing chelating resin divalent metal complexes. Int J Quantum Chem 2010;110(10):1982-93.

37. Li J, Schreckenbach G, Ziegler T. First bond dissociation energy of $\mathrm{M}(\mathrm{CO})_{6}(\mathrm{M}=\mathrm{Cr}, \mathrm{Mo}, \mathrm{W})$ Revisited: The performance of density functional theory and the influence of relativistic effects. J Phys Chem 1994;98(18):4838-41. 